\section{Moral imperialism and multi-centric clinical trials in peripheral countries}

\author{
Imperialismo moral e ensaios clínicos \\ multicêntricos em países periféricos
}

Volnei Garrafa 1

Claudio Lorenzo 2

\footnotetext{
1 Cátedra UNESCO de Bioética, Universidade de Brasília, Brasília, Brasil. 2 Universidade Federal da Bahia, Salvador, Brasil.

Correspondence V. Garrafa

Cátedra UNESCO de Bioética, Universidade de Brasília. C. P. 04451, Brasília, DF 70904-970, Brasil. bioetica@unb.br
}

\begin{abstract}
Moral imperialism is expressed in attempts to impose moral standards from one particular culture, geopolitical region or culture onto other cultures, regions or countries. Examples of Direct Moral Imperialism can be seen in various recurrent events involving multi-centric clinical trials promoted by developed (central) countries in poor and developing (peripheral) countries, particularly projects related to the theory of double standards in research. After the WMA General Assembly refused to change the Helsinki Declaration - which would have given moral recognition to the above mentioned theory - the USA abandoned the declaration and began to promote regional seminars in peripheral countries with the aim of "training" researchers on ethical perspectives that reflect America's best interests. Individuals who received such training became transmitters of these central countries' ideas across the peripheral countries, representing a form of Indirect Moral Imperialism. The paper proposes the establishment of regulatory and social control systems for clinical trials implemented in peripheral countries, through the formulation of ethical norms that reflect the specific contexts of these countries, along with the drawing up and validation of their own national norms.
\end{abstract}

Bioethics; Human Experimentation; Clinical Trial

\section{Introduction}

Bioethics has become an increasingly important issue in the 21st Century. Through the recent adoption of the Universal Declaration on Bioethics and Human Rights, unanimously approved by the 191 countries present at the 33rd Section of the General Conference of the United Nations Educational, Scientific and Cultural Organization (UNESCO), held in Paris in October 2005, bioethics has also widened its coverage: in addition to the issues of biomedicine and biotechnology already considered to be within its remit, health, social and environmental issues have been added.

Scientific research, including clinical trials, has evolved from being an amateur activity in the $18^{\text {th }}$ Century, and a university practice in the 19th Century, to an industrial activity in the 20th Century 1 . The acceleration of the process of market globalization in recent years has made clinical trials more international and influenced their means of financing as well as the development of research practices 2 .

The globalization of the world economy, rather than leading to a reduction in the gap between rich and poor across the world has further sharpened contradictions and reinforced existing problems. The majority of the populations in poor and developing (or peripheral) countries still struggle to guarantee the minimum conditions necessary for their survival and dignity. In 
Latin America, for example, the quality of public health services is generally low ${ }^{3}$, and investments in the promotion of access to pharmacotherapies on the part of underprivileged populations are almost non-existent, meaning that individuals are responsible for almost $70 \%$ of all medical-related expenses in these countries 4 . In addition, social security fails to cover approximately $40 \%$ of the populations, representing 218 million people 5 .

However, people in the upper social strata of peripheral countries make up an important consumer market of global goods and they are able to access sophisticated medical technologies.

Without the means to determine their research priorities or to make substantial in-roads in the field of public health, peripheral countries often find themselves hostages to foreign financing. This assertion is supported by data from the Word Health Organization (WHO), according to which $87 \%$ of the US $\$ 2$ trillion spent annually on health care across the globe benefits just $16 \%$ of the world's population, while $10 \%$ of the global burden of disease is responsible for as much as $90 \%$ of global expenditure on health research 6 . It is common for research performed in developing countries to be guided exclusively by the logic of the market, with the aim of developing medicines which may not be available in local public health systems in the future. In spite of criticisms of these kinds of clinical trials, many scholars, including bioethicists in developed countries, have strived to justify these views 7,8,9.

In this context, one of the most important debates has focused on placebo controlled trials. The Helsinki Declaration, the main international normative document on biomedical research, claims that the potential benefits and discomfort of a new diagnostic or therapeutic method should be compared to the benefits of current method(s) and prohibits the use of placebo groups if other effective methods already exist. However, this statement is now under strong pressure from a utilitarian rationale which places cost/benefit calculations and scientific arguments ahead of universal ethical concerns. Several authors, universities and national institutions, like the United States Food and Drug Administration, defend the morality of performing placebo controlled trials when a methodological justification exists or when there are no medicines available to developing countries' populations 10 .

Therefore, it is no surprise to note that in recent years, expressions such as "bioethics colonialism" 11 and "moral imperialism" 12,13 started to appear in scientific magazines specialized in ethics and bioethics. During the final decades of the 20th Century - encouraged by certain theoretical currents in bioethics - ethics started to be used in many instances as a horizontal and "aseptic" tool, to the service of a neutral understanding and interpretation of the collective conflicts that occur within populations that have themselves been marginalized and socially excluded from their society's development process.

Taking as a starting point an analysis of the expression "moral imperialism", the objective of this study is to critically apply the term to multicentric clinical trials that have received foreign support and been performed in several peripheral countries in the Southern Hemisphere in recent years.

\section{Moral Imperialism}

Moral Imperialism, applied to the field of bioethics, is the aim of imposing, through different forms of coercion, moral standards from specific cultures, geopolitical regions and countries on other cultures, regions, or countries 14 . The issue of imperialism is a very broad one. In spite the fact that it is a relatively recent expression (in use since around 1870), a historical retrospective study would have to discuss categories such as: colonialism, neo-colonialism and underdevelopment (as established by Marxist theories on imperialism); militarism and surplus, a new concept that substitutes more-worth (from monopolistic capitalism theory); market (social democratic theory); capitalism (liberal theory); anarchism, hegemony and State power (reason of State theory). As a general rule, in terms of political theory, imperialism means the violent expansion of a State to submit other territories to its influence or direct power and even to forms of economic exploitation, to the detriment of those subjugated States or peoples 15 .

With regard to the issues of neocolonialism and underdevelopment - both of which are directly relevant to this discussion and specifically to the peripheral countries in the world - it is important to State that uncontrolled capitalism tends to maintain and strengthen unbalanced differences between rich and poor countries, which may only be overcome by the introduction of instruments that guarantee effective regional programming and concrete regional policies with worldwide dimensions. For the field of clinical trials, the overall recommendation should be the same, an issue that will be addressed towards the end of this study.

Taking into account economic interests, particularly those of the pharmaceutical industries in developed countries, it is worth considering the problem of imposing TRIPS-Plus provisions (provisions that exceed the obligations under the 
TRIPS Agreement) into Free Trade Agreements proposed by the United States of America to peripheral countries. These provisions can significantly reduce the capacity of these countries to provide adequate access to medicines for their poorest citizens. Furthermore, strict intellectual property rules can jeopardize the development of production from the autonomous biomedical industry and erase the rights granted by the TRIPS Agreement under the World Trade Organization (WTO) 16 .

Free Trade Agreements or FTAAs have been criticized by constituency groups in the USA and in peripheral countries and risk creating tensions and antagonisms between governments and civil society in these countries. Economic and political pressures for the acceptance of such provisions broaden the gap between both sides in terms of development and health protection which is clearly a sign of moral imperialism.

This text considers imperialism as an instrument for the imposition of the cultural standards of one nation upon another, of a strong country upon more fragile ones 17. Among the fundamental principles of International Law, there are those related to the non-interference of one country into the internal affairs of another, and respect for the particular political and cultural norms of each country, with very specific exceptions. According to this line of thought and in recognition of the original meaning of the Latin word mores - meaning "way of being" or "way of proceeding", habits of a people or a nation and upon which Roman Law was established - the moral plurality of different cultures should be respected. What is now happening is that some hegemonic cultures are using their economic clout and mass communication to manipulate and invade other cultures, especially in poor and developing countries, imposing their own unilateral visions of the world. This moral imperialism transforms citizens into subjects; and the subject is a vassal, whose autonomy is very fragie or nonexistent and who is always under the control of someone stronger 17 .

We can classify moral imperialism in the field of bioethics as being direct or indirect. An example of Direct Moral Imperialism is the increasing pressure of some developed (or central) countries to impose their moral visions on others. A proof of this tendency is the recent actions (up to 2004) of the USA in imposing changes to the original content of the Helsinki Declaration on research involving human beings, with regard to the quasi-requirement of accepting as ethically correct the use of different methodological standards for different countries. That would mean the definitive acceptance that the methodological design for clinical trials (of new antiretroviral medicine, for example) should have one standard for poor countries and another for rich ones, tearing apart the theorem that held sway in the $20^{\text {th }}$ Century, recognizing the equality of all individuals 17 . It also goes against Kant's historical affirmation that human beings are an end in themselves. This distortion, defined by many scientists as "diversity of ethical criteria" 18 has been labeled double standards that is, double standards in terms of the actions of researchers and double standards in the protection of research subjects, which is incompatible with the idea of human rights, and therefore, unacceptable by peripheral countries.

Indirect Moral Imperialism, in turn, is similar to active Moral Imperialism in the way that it is applied to peripheral countries but works in a different way. It is undertaken through preliminary educative actions aimed at convincing and co-opting people in more vulnerable countries, which in the medium- and long-term may become members of ethics committees and government bodies that make decisions about the field of clinical trials.

\section{Clinical multi-centric trials in peripheral countries and their implications}

\section{Direct Moral Imperialism}

Some cases from recent world literature are considered here in order to contextualize the issue. At the end of 1997, Lurie \& Wolf 19 issued an article denouncing 15 clinical trials designed to study the prevention of vertical transmission of HIV between pregnant women and their babies in so called developing countries, using a placebo for treating the control group 19. The chief editor of the magazine, in which the article was published - The New England Journal of Medicine (N Engl J Med) - wrote an editorial supporting the authors' position, and comparing these trials to the well known "Tuskegee case" 20. This analogy was made on the grounds that the HIV trials denied antiretroviral medicines to a group of women who participated in the research in the same way that the Tuskegee study denied penicillin to the subjects, even after the acknowledged proof of its efficacy. The criticism was based on the fact that these studies violated informed consent, exceeded the grounds of placebo use and took advantage of poor and misinformed populations.

Directors of the National Institutes of Health (NIH) and the Centers for Disease Control and Prevention (CDC), both American government agencies which financed the HIV research, immediately defended the ethics of this trial, saying 
that these situations were correct, and alleging that the scientific, social and economic complexity of each trial should be considered 7 . This issue has later highlighted on the pages of magazines and newspapers with broad circulations, such as the New York Times.

The most surprising aspect was that several researchers strongly defended the adoption of different ethical criteria for trials performed in developed countries and those undertaken in poor or developing countries. The argument was based on the relativity of each situation: "Ethical standards for trials involving human beings are universal, but not absolute: there are some principles that may be applied to all cases of trials involving human beings, but their application should also consider factors inherent to the particular situations (...) which vary according to the social and economic context, besides the trial scientific conditions" 8 (p. 288).

In other words, this argument contextualizes the issue by "putting it out of context". The emerging question within the international academic community was then whether the adoption of different standards for trials and participants would be ethically justifiable. However, well-timed statements contested such arguments, maintaining that they went entirely against the improvements achieved previously, in relation to universal political and civil rights $21,22,23$. Almost two years after this event, another trial on HIV performed in poor countries has given rise to similar inquiries. This research project was developed in rural areas of Uganda, with the aim of determining risk factors associated with the transmission of HIV (type 1) among heterosexuals, trying to establish whether other sexually transmitted diseases could increase the risk of HIV infection 24 and to verify the relation between viralload and heterosexual transmission of HIV-1 25. For this trial, hundreds of people with HIV were observed for 30 months, but received no treatment and were provided with imprecise and incomplete information 26 . The perplexity raised by this trial resulted from the fact that a project of this nature would never receive approval in the USA (the country that financed the research), or any other developed country, where patients with HIV or other sexually transmitted diseases would receive prior information and treatment. It was clear that different ethical standards had been adopted for Uganda. What is even more serious is that many trials developed in peripheral countries began to be limited to observing subjects and confirming avoidable harm as, for example, in the case of the HIV positive pregnant women who were treated with a placebo. In this case, the problem was aggravated by the fact that the studies had been approved by ethical revision committees, in both the country in which they were to be implemented and in the country that financed them, an issue that will be discussed later.

What is also surprising is the fact that some Editorial Boards of scientific publications - such as the N Engl J Med and The Lancet, traditional and prestigious international publications in the biomedical sciences - accepted to publish articles with the above mentioned distortions 19,24,25. Regarding the N Engl J Med, the problem has been the subject of two editorials by Angell 20,26, who was Chief Editor of the journal at the time, both of which are critical of the decision that was taken by the board and not approved by her. She admitted that she found herself in a minority but was nevertheless unsatisfied. Soon after this affair, she left (or was forced out of) the position that she had occupied for many years. The Lancet reviewed its position through an editorial published in 2003 with the notable title of One Standard, Not Two 27. But as long as those issues raised in this present article are not considered within the context of the scientific publications themselves, including the decision to refuse publication under certain circumstances, these practices that are so negative towards more vulnerable members of society will remain in place.

Subsequent to the events mentioned above the USA, with support from many developed countries tried every means available to change the content of articles 19,29 and 30 of the Helsinki Declaration, which refers to the double standards for research involving human beings including the obligation to continue to provide treatment to subjects after the research has ended. In spite of having obtained some favorable changes following their proposals to revise the 2002 CIOMS Guidelines at the World Health Assembly in Tokyo in 2004 28, in the official discussion forum for changing the declaration, the USA's intentions were comprehensively buried by a majority of representatives from other countries. The immediate reaction of the USA was to refuse to recognize officially the Helsinki Declaration as a reference tool for clinical trials involving human beings.

More recently, at the end of 2005, the Brazilian Health Council was informed of the use of human subjects as research guinea pigs in the State of Amapá, near Brazil's northern border with Venezuela. Public investigations showed that a group of people were each paid between US\$ 6 and US\$ 10 a day to capture mosquitoes and to expose themselves to 100 bites from these mosquitoes that were infected by malaria at a rate of $3.5 \%$. 
The research was promoted by a North American University with cooperation from important Brazilian research institutions and the support of the NIH. The blood feeding of captured mosquitoes on human beings was described in the protocol approved by the Institutional Review Board of the University (this protocol is available with the authors).

The capture of mosquitoes using the "human bait" method consists of exposure of parts of the body to attract the mosquitoes and capture them before they can bite. It is a routine method employed in research as well as for entomological surveillance. According to Forattini 29 the safety of the method depends on the ability of those responsible for capturing each mosquito before it can start to bite.

The procedure, when performed by skilled technicians or researchers, seems not to present higher risks than natural exposure, although no studies have ever corroborated this. The problem of this specific research was that members of the community itself were used to capture the mosquitoes; no criteria had been determined to select the individuals involved and their training began only a few weeks before capture started. Therefore, the level of safety involved in the procedures performed by the human subjects could never be compared to those performed by experienced technicians. Nonetheless, the expression guinea pigs is not appropriate when applied here, and the sensationalist exploitation by the press has hampered the approval of research initiatives that apply the procedure correctly.

The human feeding of mosquitoes captured in nature has not been described in other articles, although it has been used in previous studies 30,31,32. Depending on the level of infection and the number of mosquitoes being fed, there are clearly significant risks involved in such a procedure, including hyper-infection, mixed infection, and other zoonotic diseases. Considering the risks involved, this procedure is totally different from other forms of research such as plasmodium inoculation for vaccine research, in which knowledge of the viral load and infection rates are far greater.

In the particular study under discussion here, it was established that individuals would allow themselves to be bitten by 100 mosquitoes, twice a year. There is no mention of the number of days during which this procedure would be undertaken. The researcher in charge of field activities admitted openly that the period of exposure was planned to be four nights but that the procedure was performed only once and then cancelled. Notwithstanding, according to members of the riverside community where the research was conducted, exposure lasted for four nights at a time.

At two different stages in the original protocol, blood feeding by mosquitoes on human beings is mentioned clearly. The chapter that describes the methodology to be employed states that: "Mosquitoes captured from human landing counts will be blood-fed on team member volunteers who have taken the recommended Ministry of Health malaria prophylaxis for the region" (p. 37) and in the description of the participation of the individuals, it states: "The team volunteers who blood feed the mosquitoes during the markrecapture experiments will be provided with the current Ministry of Health recommendation for chemoprophylaxis in this region" (p. 43). The document of informed consent signed by research subjects also includes a clear description of the procedure in its item 6: “... you will be requested to feed 100 mosquitoes from your arm or leg for studies of marking-recapture. That will happen twice a year" (informed consent attached to the protocol; p. 2). It is clear that the reasoning used by the International Review Board to accept such a high degree of risk was based on double standards.

The public presentation by the Brazilian Health Council of the investigators' report in April 2006, showed that the blood feeding procedure and the capture of mosquitoes through exposure of members of the local communities were omitted in the Portuguese translation of the protocol, and were also omitted in the consent document received by the National Commission on Ethics in Research (CONEP). As the English original version cannot be examined without translation by a Brazilian Commission, the protocol was also approved in Brazil and the research began. The acknowledgement of these facts caused the immediate suspension of the research by the Brazilian Health Council and the publication of its results was forbidden.

\section{Indirect Moral Imperialism}

A paradigmatic text written by Emanuel \& Grady 33 and published in January 2007, proposes a historical classification of four different phases relating to the development of clinical trials: (1) the "researcher paternalism" phase from 1940 to the beginning of the 1970s labeled "utilitarianism"; (2) between the start of the 1970s and the mid-1980s, a phase known as "principalism"; (3) the "participant access" phase, between the mid-1980s and the mid-1990s, referring to basic individual rights and informed consent; and (4) the "community partnership" phase, from the mid-1990s to the present, represented by com- 
munitarian actions in the form of cooperation between institutions, people and countries.

This chronology is consistent with the line of action proposed by the NIH in relation to peripheral countries, starting with the USA's rejection of the Helsinki Declaration in December 2004. The USA formally declared to the world that from that moment on, their researchers and the trials financed by their companies should follow their own guidelines, based on the ICH-GCP guidelines (International Conference on the Harmonization - Good Clinical Practices). These guidelines reflect the tripartite agreement made in 1997 between America, Japan and Europe, which are the world's three leading medicine producers. As mentioned previously, the 2002 CIOMS version also includes changes that reflect these pressures.

More recently, USA changed its strategy to avoid international confrontation. It now promotes frequent academic meetings in different countries with the support of the Fogarty International Center, an institute of the NIH, with the aim of "instructing" researchers from peripheral countries in their particular way of interpreting the ethics of clinical trials, independently of the views of the governments of the countries from which these researchers hail 34. In Latin America, for example, many activities of this kind have been developed in Argentina, Chile and Venezuela over the last three years. The strategy implies that once these researchers have been appropriately "drilled", they should start participating in Research Ethics Committees in their own countries, and in bodies that regulate such issues within their national governments. In this way, in just a few years, Emanuel \& Grady's 33 paradigmatic proposal may become reality, since decisions related to ethics in clinical trials in different countries would be taken concretely and coherently by societies and communities. It thus represents a more subtle form of ethical imperialism. Tealdi 34 reports that in 10 years it would be possible to "instruct" 3,600 people in Latin America alone, changing some of the core references for ethics in clinical trials up to 2010, when the next revision of the Helsinki Declaration is due.

\section{Regulation and control of trials in periphery countries}

At this point in the text we present a proposal for the development of systems for the regulation and social auditing of research in peripheral countries. These systems could be crucially important in guaranteeing significant changes in the current situation, and be to the benefit of vulnerable populations. This proposal has been presented to the Latin American and Caribbean Bioethics Network of UNESCO (Redbioética) - and was also included in its first course on ethics in trials involving human beings in the program for distance learning and permanent education 2 .

The development of a system for the regulation and social auditing of research in poor and developing countries that is capable of promoting cooperation in international research, and limiting moral imperialism and exploitation in international research would, in this proposal, involve reform along two main lines: (1) the drawing up of strict norms that are relevant to the socioeconomic and cultural contexts of these countries, involving the three axes of protection in research ethics (obtaining consent, minimization of risks and maximization of benefits); (2) reform of the socio-political component, through the creation of normative regulatory instruments in the form of laws and ethical norms in research and the opening up of democratic spaces for social auditing, embodied in institutional or regional committees and national commissions for clinical trials.

With regard to proposal 1 - the design of norms that are relevant to the socioeconomic and cultural contexts of peripheral countries - there are three components to be considered: (a) improve the processes for obtaining informed consent, by giving less importance to the contractual neo-liberal approach and more importance to a communitarian vision of autonomy for populations with low levels of education; (b) improve procedures aimed at minimizing risks to ensure equality for all subjects who participate in clinical trials; (c) improve procedures aimed at maximizing benefits, for this same reason.

In relation to proposal 2 - the creation and validation of national norms - there are also three components to be considered: (a) stimulate sociopolitical participation in the production of documents through independent and interdisciplinary discussion forums, with the aim of obtaining a national consensus on ethical limits in research; (b) create national or institutional spaces for the evaluation of the ethical aspects of research protocols, with independent decision-making capacities and ethical overview of research; (c) build the capacities of members of ethics committees and commissions in the following areas: knowledge development of ethical norms for trials and their interpretation, with relevance to the local context; knowledge development about the degree of risk of human participation depending on the main methodological techniques of research (here scientific issues can 
be simplified in order to make them accessible to individuals who are not themselves researchers in the area of health); training on communication, developing arguments and on the critical analysis of certain arguments, to support decision-making processes.

\section{Final considerations}

The "partnership society" proposed by Emanuel \& Grady 33 may come about as a result of actions by the USA which seek to promote the passive acceptance of research projects as a result of rich (central) countries' interests in peripheral countries. In such a scenario, many of those who participate in the decision-making process in poor and developing countries would receive the appropriate "drilling" on the new/old ways of thinking, and assume that supposedly universal, but imperialist ethics are in fact appropriate ethics for their populations. This could be considered to be an example of the ideology of double standards or the persuasion of researchers through special methods of "instruction" on research ethics.

Nonetheless, it is important to highlight the resistance of some countries in the Southern Hemisphere to attempts to import bioethical colonialism and to acknowledge the benefits of ethical imperialism. Redbioética, a network created with the support of the Regional UNESCO Bureau in Mexico, is proof of such resistance and is critical of importing "ethical packages" into different contexts and cultures.

Redbioética is fully open to bilateral exchanges with other institutions, countries and regions of the world, aimed at sharing experience and best practice. In recent years, some Latin American countries have provided concrete responses to ethical invasions, through improving legislation and academic programs for clinical researchers and bioethicists, which are more critical and concerned with the sociopolitic feedback of their trials, thus creating a new culture of public participation, citizenship and social responsibility.

\section{Resumo}

Imperialismo moral é a intenção de impor padrões morais de determinadas culturas, regiões geopolíticas e países a outras culturas, regiões ou países. $O$ Imperialismo Moral Direto pode ser exemplificado com diversos episódios recorrentes de ensaios clínicos multicêntricos promovidos por países desenvolvidos (centrais) em países pobres e em desenvolvimento (periféricos), especialmente projetos relacionados com a teoria do "double standard" de pesquisas. Com a recusa da Assembléia Geral da Associação Médica Mundial em alterar a Declaração de Helsinki, que significaria o reconhecimento moral da referida teoria, os Estados Unidos abandonaram a declaração, passando a promover seminários regionais em países periféricos com objetivo de "treinar" investigadores nas visões éticas dos interesses estadunidenses. Estes passam a ser duplicadores das idéias centrais, em diferentes instâncias das nações periféricas, caracterizando uma forma de Imperialismo Moral Indireto. O estudo propõe a construção de sistemas de regulação e de controle social para os ensaios clínicos a serem implementados nos países periféricos, por meio da formulação de normas éticas adequadas às características contextuais destes países, conjuntamente com a criação e validação de documentos normativos nacionais próprios.

\section{Contributors}

Both authors worked on all phases of the research, including design, literature review and writing up the final article. 


\section{References}

1. Ravetz J. Scientific knowledgement and its social problems. Oxford: Oxford University Press; 1971.

2. Garrafa V, Lorenzo C. Ética e investigación clínica en los países en desarrollo - aspectos conceptuales, técnicos y sociales. Córdoba: Red Latino-Americana y del Caribe de Bioética de UNESCO; 2006.

3. Rosemberg H, Peña M. Dimensions of exclusion from social protection in health in Latin America and the Caribbean. Washington DC: Pan American Health Organization; 2000.

4. Vieira C. Globalización, comercio internacional y equidad en materia de salud. Rev Panam Salud Pública 2002; 11:425-9.

5. Rosemberg H, Andersson B. Repensar la protección social en salud en América Latina y el Caribe. Rev Panam Salud Pública 2000; 8:118-25.

6. Singer P, Benatar S. Beyond Helsinki: a vision for global health ethics. BMJ 2001; 322:747-8.

7. Varmus H, Satcher D. Ethical complexities of conducting research in developing countries. N Engl J Med 1997; 337:1000-5.

8. Resnik DB. The ethics of HIV research in developing nations. Bioethics 1998; 12:286-306.

9. Capron A. Power and injustice in research involving human subjects. In: Annals of the Sixth World Congress of Bioethics. Brasília: International Association of Bioethics/Sociedade Brasileira de Bioética; 2002. p. 83.

10. Rothman K, Michels K, Baum M. Declaration of Helsinki should be strengthened. BMJ 2000; 321:442-5.

11. Chadwick R, Schüklenk U. Bioethical colonialism? [Editorial]. Bioethics 2004; 18:iii-iv.

12. Benatar SR. Imperialism, research ethics and global health. J Med Ethics 1998; 24:221-2.

13. Dawson A, Garrard E. In defense of moral imperialism: four equal and universal prima facie principles. J Med Ethics 2006; 32:200-4.

14. Garrafa V. Imperialismo ético (verbete). In: Tealdi JC, editor. Diccionário latino-americano de bioética. Bogotá: Unibiblos/Organización de las $\mathrm{Na}$ ciones Unidas para la Educación, la Ciencia y la Cultura; in press.

15. Bobbio N, Matteucci N, Pasquino G. Dicionário de política. Brasília: Editora da Universidade de Brasília; 2004

16. World Trade Organization. Trade related aspects of intellectual property rights. http://www.wto.org/ english/docs_e/legal_e/27-trips_01_e.htm (accessed on 05/Sep/2007).

17. Garrafa V, Prado MM. Mudanças na Declaração de Helsinki: fundamentalismo econômico, imperialismo ético e controle social. Cad Saúde Pública 2001; 17:1489-96.

18. Lie RK, Emanuel E, Grady C, Wendler D. The standard of care debate: the Declaration of Helsinki versus the international consensus opinion. J Med Ethics 2004; 30:190-3.
19. Lurie P, Wolfe S. Unethical trials of interventions to reduce perinatal transmission of the human immunodeficiency virus in developing countries. N Engl J Med 1997; 337:853-6.

20. Angell M. The ethics of clinical research in third world [Editorial]. N Engl J Med 1997; 337:847-9.

21. Schüklenk U. Unethical perinatal HIV transmission trials establish bad precedent. Bioethics 1998; 12:312-8.

22. Thomas J. Ethical challenges of HIV clinical trials in developing countries. Bioethics 1998; 12:320-7.

23. Greco D. A cure at any cost? New Sci 2001; 167: 42-3.

24. Wawer MJ, Sewankambo NK, Serwadda D, Quinn TC, Paxton LA, Kiwanuka N, et al. Control of sexually transmitted diseases for AIDS prevention in Uganda: a randomised community trial. Rakai Project Study Group. Lancet 1999; 353:525-35.

25. Quinn TC, Wawer MJ, Sewankambo N, Serwadda D, Li C, Wabwire-Mangen F, et al. Viral load and heterosexual transmission of human immunodeficiency virus type 1. Rakai Project Study Group. N Engl J Med 2000; 342:921-9.

26. Angell M. Investigators' responsibilities for human subjects in developing countries [Editorial]. N Engl J Med 2000; 342:967-9.

27. Carlson R, Boyd K, Webb D. One standard, not two [Editorial]. Lancet 2003; 362:1761.

28. Regional Office for the Western Pacific, World Health Organization. Regional committee for the Western Pacific fifty-third session. Report of the regional committee summary records of the plenary meetings. Manila: Regional Office for the Western Pacific, World Health Organization; 2002.

29. Forattini OP. Coulicidologia médica. v. 2. São Paulo: Edusp; 1997.

30. Roberts DR, Alecrim WD, Tavares AM, McNeill KM. Field observations on the gonotrophic cycle of Anapheles darlingi (Diptera: Culicidae). J Med Entomol 1983; 20:189-92.

31. Charlwood JD, Alecrim WA. Capture-recapture studies with the South American malaria vector Anopheles darlingi. Ann Trop Med Parasitol 1989; 83:569-76.

32. Santos R, Forattini O, Burattini M. Laboratory and field observations on duration of gonotrophic cycle of Anopheles albitarsis (Diptera: Culicidae) in Southern Brazil. J Med Entomol 2002; 39:926-30.

33. Emanuel EJ, Grady C. Four paradigms of clinical research and research oversight. Camb Q Healthc Ethics 2007; 16:82-96.

34. Tealdi JC. Historia y significado de las normas éticas internacionales sobre investigaciones biomédicas. In: Keyeux G, Penchaszadeh V, Saada A, editores. Investigación en seres humanos y políticas de salud pública. Bogotá: Universidad Nacional de Colombia/Red Latino-Americana y del Caribe de Bioética de UNESCO; 2006. p. 33-62.

Submitted on $03 / \mathrm{Jul} / 2007$

Final version resubmitted on $04 /$ Oct/2007 Approved on 25/Oct/2007 